\title{
Prevalence of lameness, claw lesions, and associated risk factors in dairy farms in Selangor, Malaysia
}

\author{
M. B. Sadiq ${ }^{1}$ - S. Z. Ramanoon ${ }^{1,2}$ • R. Mansor ${ }^{2,3}$ - S. S. Syed-Hussain ${ }^{2,3}$. \\ W. M. Shaik Mossadeq ${ }^{4}$
}

Received: 10 April 2017 / Accepted: 17 August 2017 /Published online: 31 August 2017

(C) The Author(s) 2017. This article is an open access publication

\begin{abstract}
The objectives of this cross-sectional study were to estimate the prevalence of lameness, claw lesions, and associated risk factors in dairy farms in Selangor, Malaysia. The sample population was 251 lactating cows from 8 farms assessed for lameness and claw lesions by locomotion scoring and claw assessment respectively while specific animal-based measures were hypothesized as cow-level risk factors. The Wilcoxon rank test and logistic regression were applied to assess the prevalence of lameness, claw lesions, and association with potential risk factors, respectively. The prevalence of lameness was $19.1 \%$ ranging from 10.0 to $33.3 \%$ while $31.1 \%$ of cows had claw lesions and ranged from $16.3-40 \%$. Claw lesions were recorded in $87.5 \%$ of the lame cows with highest being those affected with sole lesions $(54.2 \%)$ and white line disease (61.2\%). Overall, the occurrence of overgrown claws, sole lesions, white line disease, and digital dermatitis were 37, $18.2,10.9$, and $8.3 \%$, respectively. More than one claw lesion per cow was present in $71.8 \%$ of the affected cows. Lameness was associated with early lactation ( $\mathrm{OR}=3.3 ; 95 \%$ CI $2-7)$, injured hocks ( $\mathrm{OR}=4.8 ; 95 \%$ CI 5-17), and dirty legs hygiene
\end{abstract}

S. Z. Ramanoon

sramanoon@upm.edu.my

1 Department of Farm and Exotic Animal Medicine and Surgery, Faculty of Veterinary Medicine, Universiti Putra Malaysia, 43400 UPM Serdang, Selangor, Malaysia

2 Centre of Excellence (Ruminant), Faculty of Veterinary Medicine, Universiti Putra Malaysia, 43400 UPM Serdang, Selangor, Malaysia

3 Department of Veterinary Clinical Studies, Faculty of Veterinary Medicine, Universiti Putra Malaysia, 43400 UPM Serdang, Selangor, Malaysia

4 Department of Veterinary Preclinical Sciences, Faculty of Veterinary Medicine, Universiti Putra Malaysia, 43400 UPM Serdang, Selangor, Malaysia
$(\mathrm{OR}=2.6 ; 95 \% \mathrm{CI} 1.3-6.2)$, whereas presence of claw lesions was associated with dirty legs hygiene $(\mathrm{OR}=4.7 ; 95 \% \mathrm{CI} 4$ 11 ) and overgrown claw (OR $=2.7 ; 95 \%$ CI 1.4-5.3). To reduce the prevalence of lameness, farmers need to improve the management of cows with overgrown claw, injured hocks, and cleanliness by establishing routine claw trimming and efficient stall design.

Keywords Lameness prevalence $\cdot$ Claw lesions $\cdot$ Dairy cows $\cdot$ Risk factors $\cdot$ Locomotion

\section{Introduction}

Dairy production is fast growing in South Asia with indications of the highest global demand for milk emanating from the region (FAO 2015). However, the growing intensive management of cattle dairy herds and demand for high milk yield has increased their susceptibility to certain productionlimiting conditions such as lameness (Cook et al. 2016). Lameness is a condition characterized by alteration of gait resulting from pain caused by injury to the hoof or limb (Olechnowicz and Jaskowski 2011). Lameness in dairy cows is a welfare problem (Whay and Shearer 2017) and causes economic loss attributed to early culling, treatment, of and reduced milk yield (Green et al. 2014; Thomas et al. 2016). The prevalence of lameness varies amongst herds between regions and countries as cow level prevalence of lameness was 21.98 and $18.9 \%$ in western Thailand (Rahman et al. 2014) and Australian dairy herds, respectively (Ranjbar et al. 2016). In India, a recent study reported incidence of lameness of $17.2 \%$ in contrast to $9.4 \%$ recorded previously (Asit and Pankaj 2016). Therefore, lameness occurrence might differ in the tropics due to diverse management practices influencing the predominance of associated risk factors. 
Claw lesions have been reported to be majorly responsible for lameness conditions in dairy herds (Somers and O'Grady 2015; Solano et al. 2016). The disease process of claw lesions and specifically those affecting the claw horn tissues is not fully understood. Nevertheless, events such as nutritionalinduced inflammation (Thoefner et al. 2004) hard floor surfaces (Bergsten et al. 2015) and physiological changes affecting the digital cushion (Newsome et al. 2017) have been shown to influence development of claw lesions. Claw lesions have also been found as subclinical affections in non-lame cows while (Tadich et al. 2010), however, reduced milk yield was reported in cows with subclinical claw lesions prior to the onset of lameness (Green et al. 2014). Hence, investigating the presence of claw lesions and clinical lameness in dairy cows is essential as the use of only locomotion scoring often underestimate the presence of claw lesions (van Nuffel et al. 2015).

In Malaysia and Selangor specifically, there is dearth information on claw health status and lameness in dairy despite recent growth in the dairy industry. Information from the large animal ward records of the institution veterinary teaching hospital reported a total of 79 lameness cases from the Ladang Angkat farms from the year 2013-2016 (Unpublished work). However, international studies have showed that farmers often underestimate lameness occurrence and present only severe cases for treatment (Horseman et al. 2014). Therefore, the objectives of this study were to investigate the prevalence of lameness, claw lesions, and associated risk factors amongst dairy herds in Selangor, Malaysia.

\section{Materials and methods}

The study was carried out in Selangor on the west coast of Peninsular Malaysia, approx. $3^{\circ} 20^{\prime} \mathrm{N}$ and $101^{\circ} 30^{\prime} \mathrm{E}$ (Fig. 1). Eighteen dairy farmers registered with the Department of Veterinary Services (DVS 2014) were contacted by phone seeking their consent to participate in the study. The criteria for farm selection included intensive and free-stall management, herd size $\geq 50$, and presence of 20 or more lactating cows. Eight dairy farms willing to participate and plausible for the study were selected and visited between September 2016 and February, 2017. Sample size was 251 lactating cows, a value chosen by taking into account expected lameness prevalence of $20 \%$, confidence level of $95 \%$, and desired precision of 5\% as described by Thrusfield (2005). All the cows enrolled were the Mafriwal breed, a cross between Fresian and Sahiwal. Within each herd, 50\% of all lactating cows were sampled and stratified based on parity and days in milk (DIM). Animal-based measures such as body condition score (BCS), hock condition score (HCS), and leg hygiene were recorded for each cow before assessing the locomotion score (LS).

Herd features such as herd size, number of milking cows, number of cows at early days in milk (DIM), and access to pasture were obtained from farm records and selfadministered questionnaire. For management practices related to claw health, two farms had a routine claw trimming program while only one used a footbath. Also, four farms had rubber mats as stall base for individual cows.

The BCS was recorded using a 1 to 4 scale (Elanco animal health 2009) as thin, poor, moderate, and fat. Hind limbs were examined for hock condition score on 3 levels scale where, $1=$ normal area with no alopecia and inflammation, $2=$ hair loss but absence or slight swelling $(<-12 \mathrm{~cm})$, and $3=$ hair loss and substantial swelling (> $2 \mathrm{~cm}$ ) (Gibbons et al. 2012). Leg hygiene was scored depending on the level of manure contamination of the upper and lower limbs as described by Solano et al. (2015). Lameness was assessed by using a modified 4-point locomotion score developed by DairyCo (2007) (Table 1). This involved the detailed visual examination of the posture and gait of the animal while leaving the milking palour on a flat surface.

Following restraining, the rear claw was cleaned and debris removed for clear visualization of the claw zones. Claw length was assessed using a claw check and claw angles above $45^{\circ}$ were considered overgrown (Archer et al. 2015). Claw lesions
Fig. 1 Map of Peninsular Malaysia showing the location of the study site. The enlargement of the study site indicates the location of the dairy farms (black dots) and the black arrow depicts north (Quantum GIS 2.4.0 Chugiak)

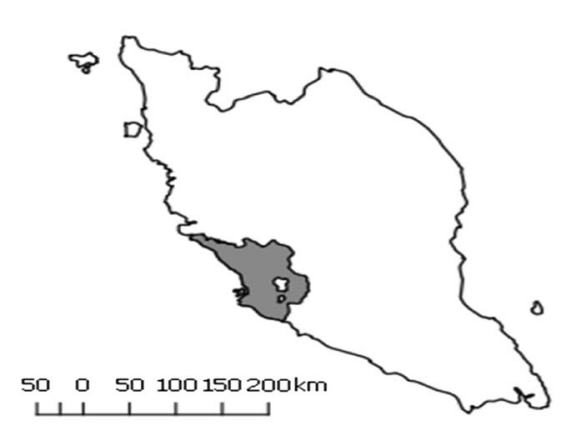

$10010203040 \mathrm{~km}$

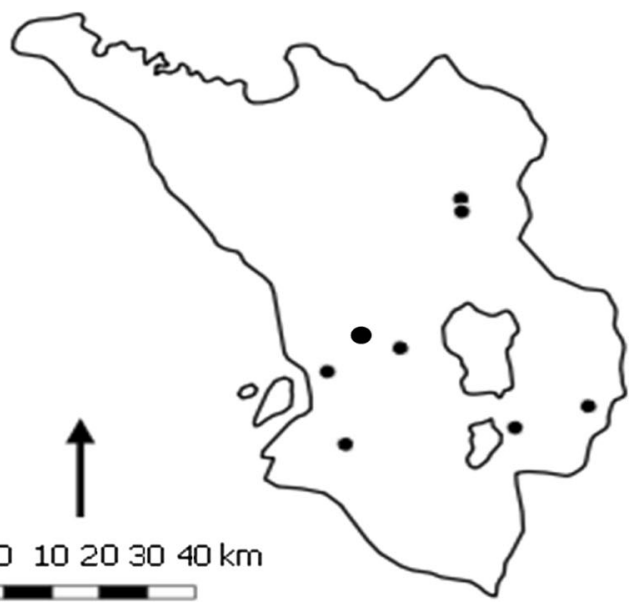


Table 1 Locomotion scoring chart used in the study farms

\begin{tabular}{lll}
\hline $\begin{array}{l}\text { Lameness } \\
\text { score }\end{array}$ & $\begin{array}{l}\text { Clinical } \\
\text { description }\end{array}$ & Assessment criteria \\
\hline 1 & $\begin{array}{l}\text { Sound } \\
\text { Sound }\end{array}$ & $\begin{array}{l}\text { The cow stands and walks with a level-back posture. Her gait is normal. } \\
\text { The cow stands with a level-back posture, but develops an arched-back posture } \\
\text { while walking. Her gait is normal. }\end{array}$ \\
3 & Lame & $\begin{array}{l}\text { An arched-back posture is evident both while standing and walking. Her gait is } \\
\text { affected and is best described as short striding with one or more limbs. } \\
\text { An arched-back posture is always evident and gait is best described as one } \\
\text { deliberate step at a time. The cow favors one or more limbs or feet to inability } \\
\text { to bear weight on one or more of her limbs }\end{array}$ \\
\hline
\end{tabular}

Source: a modified locomotion scoring system developed by DairyCo (2007) were grouped into those affecting the hoof skin and claw horn lesions. The former consisted of digital dermatitis (DD) and heel horn erosion, interdigital hyperplasia (IH), and swelling of the coronet area (SC). Claw horn lesions included sole lesions (hemorrhage, ulcer, bruises, and double sole) (SL), white line disease (WLD), heel lesions, (HL), wall fissures (WF), overgrown claw with deformities (OC), and others (corkscrew and scissors claw) as described by Shearer and Van Amstel (2013) and the International Claw Health Atlas (2015). Different claw lesions were counted per cow whereas presence of more than one of the same lesion in a cow was recorded once.

All statistical analyses were performed using IBM SSPSS 24 (Version 24.0, IBM Corp., and Chicago, IL, USA). Data based on the assessment scoring system were screened for normality using the Shapiro-Wilk test and the distribution was non-normal. Prevalence of lameness and claw lesions was calculated as the total number of cows with LS $\geq 3$ and affected with $\geq 1$ or more claw lesion to the total number of observed cows in each farm. The Wilcoxon signed rank test and descriptive statistics were used to compare the prevalence estimates distribution of claw lesions, respectively. A binary logistic regression with forward procedure was applied to investigate cow level factors associated with prevalence of lameness and claw lesions. Model fit for the dataset was assessed by using the Pearson chi-square statistic and the Hosmer-Lemeshow test. Odds ratio (OR) was read from the parameter estimates at $95 \%$ confidence interval (CI) and $P$ value $<0.05$ was considered significant.

\section{Results}

In all the dairy cows (251) examined, cow prevalence of lameness was $19.1 \%$ and ranged from 10.0 to $33.3 \%$ amongst the studied farms (see Table 2). Statistical test revealed a significant
Table 2 Prevalence of lameness and cows affected with claw lesions in the study farms based on LS and claw assessment, respectively

\begin{tabular}{|c|c|c|c|c|c|c|c|c|}
\hline \multirow[t]{2}{*}{ Farms } & \multirow{2}{*}{$\begin{array}{l}\text { No. of } \\
\text { cows }\end{array}$} & \multirow[t]{2}{*}{ Observation } & \multicolumn{3}{|l|}{ Lame cows } & \multicolumn{3}{|c|}{ Claw lesions } \\
\hline & & & $\begin{array}{l}\text { No. of lame } \\
\text { cows }\end{array}$ & $\%$ & $\begin{array}{l}95 \% \\
\mathrm{CI}\end{array}$ & $\begin{array}{l}\text { Cows } \\
\text { affected }\end{array}$ & $\%$ & $\begin{array}{l}95 \% \\
\text { CI }\end{array}$ \\
\hline F1 & 82 & 40 & 4 & 10.0 & $0.7-19$ & 10 & 25.0 & $6-29$ \\
\hline $\mathrm{F} 2$ & 34 & 26 & 5 & 19.2 & $4-34$ & 7 & 26.9 & $7-39$ \\
\hline F3 & 86 & 40 & 10 & 25.0 & $14-41$ & 14 & 35.0 & $23-53$ \\
\hline $\mathrm{F} 4$ & 100 & 49 & 7 & 14.3 & $5-24$ & 11 & 22.4 & $6-27$ \\
\hline F5 & 64 & 30 & 10 & 33.3 & $17-50$ & 12 & 40.0 & $23-58$ \\
\hline F6 & 38 & 16 & 2 & 12.5 & $0-29$ & 6 & 37.5 & $14-61$ \\
\hline F7 & 43 & 20 & 4 & 20.0 & $3-38$ & 8 & 40.0 & $23-67$ \\
\hline F8 & 72 & 30 & 6 & 20.0 & $6-34$ & 10 & 33.3 & $14-46$ \\
\hline Total & 519 & 251 & 48 & 19.1 & & 78 & 31.1 & \\
\hline Median \pm range & $68 \pm 66$ & $30 \pm 33$ & $5.5 \pm 8$ & & & $7 \pm 8$ & & \\
\hline $\begin{array}{l}\text { Wilcoxon } \\
\text { signed rank }\end{array}$ & & & -2.50 & & -2.40 & & & \\
\hline$P$ value & & & $0.012 *$ & & $0.011 *$ & & & \\
\hline
\end{tabular}

$F$ farms, values numerical notation of farms

$P$ values $<0.05$ are statistically significant 
Table 3 Number of cows diagnosed with each claw lesion and corresponding number of lame cows

\begin{tabular}{|c|c|c|c|c|c|c|}
\hline \multirow[t]{2}{*}{ Claw lesions } & \multirow[t]{2}{*}{ Frequency } & \multirow[t]{2}{*}{$\%$} & \multicolumn{2}{|l|}{ Lame cows } & \multicolumn{2}{|c|}{ Non-lame cows } \\
\hline & & & Observations & $\%$ & Observations & $\%$ \\
\hline SL & 35 & 18.2 & 19 & 54.2 & 16 & 45.8 \\
\hline WLD & 21 & 10.9 & 13 & 61.9 & 7 & 38.1 \\
\hline DD & 16 & 8.3 & 13 & 81.2 & 3 & 18.7 \\
\hline $\mathrm{SC}$ & 5 & 2.6 & 5 & 100 & 0 & 0.0 \\
\hline $\mathrm{IH}$ & 6 & 3.1 & 1 & 16.7 & 5 & 83.3 \\
\hline HL & 12 & 6.3 & 6 & 50.0 & 6 & 50.0 \\
\hline WF & 17 & 8.9 & 5 & 29.4 & 12 & 70.6 \\
\hline $\mathrm{OC}$ & 71 & 37.0 & 25 & 35.2 & 46 & 64.8 \\
\hline Others & 9 & 4.7 & 1 & 11.1 & 8 & 88.9 \\
\hline Total (\%) & 192 & 100 & $88(45.8)$ & 100 & $104(54.2)$ & \\
\hline
\end{tabular}

$S L$ sole lesions, $W L D$ white line disease, $D D$ digital dermatitis, $S C$ swelling of the coronet area, $I H$ interdigital hyperplasia, $H L$ heel lesions, $W F$ wall fissures, $O C$ overgrown claw with deformity, others corkscrew claw and avulsion difference $(P<0.05)$ in the prevalence of lameness amongst the farms. Cow prevalence of claw lesions was $31.1 \%(78 / 251)$ ranging from 16.3 to $40.0 \%$ amongst the studied farms. The distribution and occurrence of claw lesions in the affected cows are presented in Table 3. A total of 192 claw lesions were recorded with the most recurrent being OC (37.0\%), SL (18.2\%), WLD (10.9\%), WF (8.9\%), and DD (8.3\%). Other recorded claw lesions included SC (2.6\%), IH (3.1\%), HL $(6.3 \%)$, and others $(4.7 \%)$. The proportion of cows with single claw lesion was $28.2 \%$ whereas $71.8 \%$ had combination of either 2 or more lesions. Cows affected with WLD, SL, and DD had the highest corresponding lame cows being 61.2, 54.2, and $81.2 \%$, respectively. However, though the occurrence of $\mathrm{SC}$ was low, all the affected cows were lame (Fig. 2). Overall, claw lesions were recorded in $87.5 \%$ (42/48) of the lame cows. The herd prevalence of the claw lesions showed that SL, WLD, $\mathrm{WF}$, and $\mathrm{OC}$ were all recorded in the farms while DD was not diagnosed in 2 farms. SL was mostly found in association with OC (47.0\%), IH (33.3\%), WLD (23.0\%), and SC (20.0\%). OC was also present with WLD (34.0\%) and WF (46\%) while $12.0 \%$ had combined lesions of DD and WLD (Fig. 3).

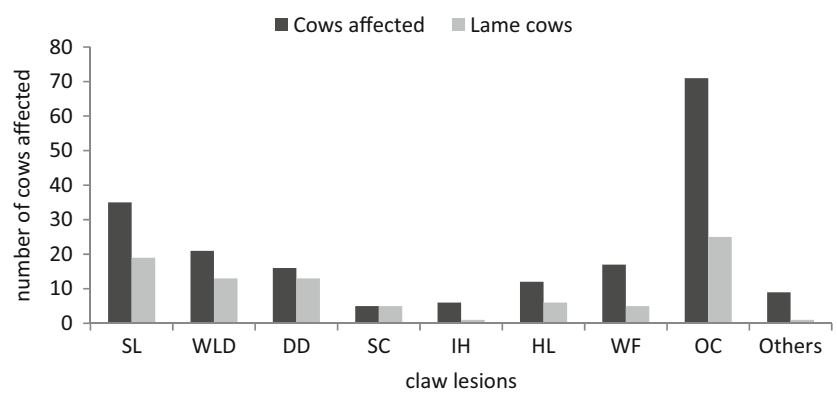

Fig. 2 Distribution of claw lesions and the number of lame cows. Keys: SL sole lesions, WLD white line disease, DD digital dermatitis, SC swelling of the coronet area, IH interdigital hyperplasia, HL heel lesions, WF wall fissures, and OC overgrown claw with deformities
The prevalence of lameness was not associated with parity $(P>0.05)$ whereas cows in early lactation were significantly associated (OR $=3.3 ; 95 \%$ CI 2-7.) with lameness occurrence compared to those in late lactation. Thin cows had the highest lameness prevalence (27.5\%) but was not significantly different while fat cows $(\mathrm{BCS}>3)$ were a protective factor $(\mathrm{OR}=0.3$; 95\% CI 0.1-1). However, lameness was associated with injured hocks (OR $=4.8 ; 95 \%$ CI 5-17) as well as cows which had dirty and very dirty leg hygiene score with approximately 3 and 10 times increased odds of being lame (Table 4). Despite the higher prevalence of lameness in cows with overgrown claw (31.9\%), the association tends not to be significant $(P>0.05)$. For cows with claw lesions, prevalence was associated with overgrown claw $(\mathrm{OR}=2.7 ; 95 \% \mathrm{CI} 1.4-5.3)$ and dirty leg hygiene score $(\mathrm{OR}=4.7 ; 95 \% \mathrm{CI} 4-11)$ (Table 5$)$.

\section{Discussion}

The cow prevalence of lameness of $19.1 \%$ with herd prevalence ranging from 10 to $33 \%$ reported in this study is similar to that presented in Bangladesh and China (Rahman et al. 2014; Chapinal et al. 2014) and different from that reported in Switzerland and Ireland (Becker et al. 2014; Somers and O'Grady 2015). The disparity could be due to variation in herd size, management practices, and diagnostic criteria (Tadich et al. 2010). The present study recorded cow prevalence of claw lesions of $31.1 \%$ being responsible for $87 \%$ of the recorded lameness cases. Furthermore, OC, SL, and WLD were the recurrent claw lesions and similar to the findings from other studies (Zahid et al. 2014; Somers and O'Grady 2015). However, claw lesions other than OC were reported in other studies due to routine claw trimming practices which were lacking in most of the farms enrolled in this study. 
Fig. 3 Claw lesions and their simultaneous occurrence in the dairy cows. Keys: SL sole lesions, WLD white line disease, DD digital dermatitis, SC swelling of the coronet area, IH interdigital hyperplasia, HL heel lesions, WF wall fissures, and OC overgrown claw with deformities

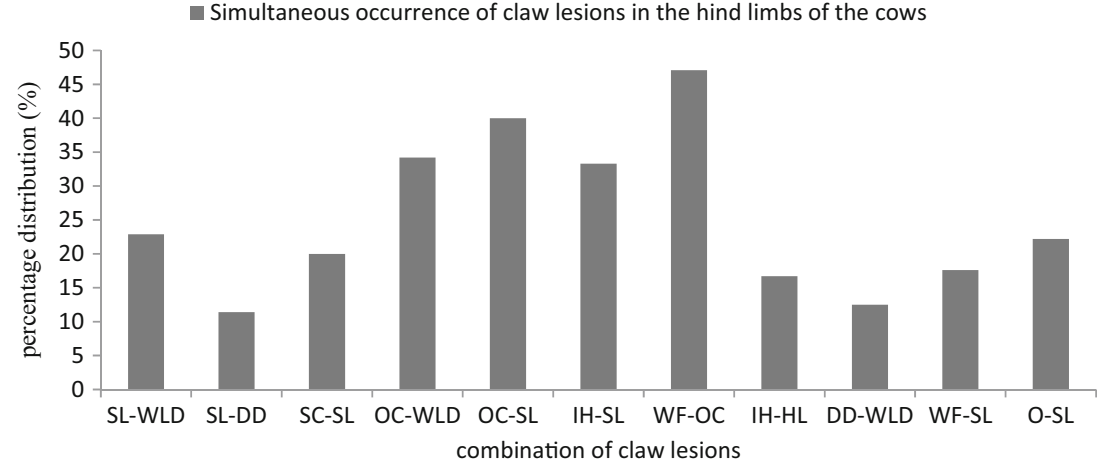

Also, the high prevalence of SL and WLD might be attributed to the hard concrete floor which exposes the solar and white line area to greater forces leading to traumatic claw lesions (Shearer 2017).

A higher proportion of cows affected with SC, DD, and WLD were lame compared to those with SL and OC which could be attributed to the distribution and simultaneous occurrence of respective claw lesions. Also, factors such as severity, stage, and duration are vital in the association between claw lesions and lameness (Palmer and O'Connell 2015; Shearer 2017). Accordingly, majority of the affected cows had more than one claw lesion in this study and consistent with other studies (Olechnowicz et al. 2011; Solano et al. 2015). The likelihood for more than one claw lesion per cow could be due to complication of primary lesions and chronic tendency of lesions such as SL, WLD, and DD (Bergsten et al. 2015; Gomez et al. 2015).

Lameness prevalence in this study was not significantly associated with BCS and parity which contradicts finding from other authors (Green et al. 2014; Solano et al. 2015). Differences might be due to system of BCS, sample size, breeds, and corresponding milk yielding capacity. However,
Table 4 Relationship between cow level factors and occurrence of lameness in the dairy cows using binary logistic regression

\begin{tabular}{|c|c|c|c|c|c|c|}
\hline Factors & Observations $(n=251)$ & $\begin{array}{l}\text { Lame cows } \\
(n=48)\end{array}$ & $\%$ & OR & $95 \% \mathrm{CI}$ & $P$ value \\
\hline \multicolumn{7}{|l|}{ Parity } \\
\hline Primiparous & 59 & 18 & 30.5 & Ref & & \\
\hline Second parity & 103 & 13 & 12.6 & 0.9 & $0.3-3$ & 0.81 \\
\hline Parity 3 and above & 99 & 27 & 27.2 & 1.6 & $0.6-4$ & 0.38 \\
\hline \multicolumn{7}{|l|}{ DIM } \\
\hline 1-120 days in milk & 130 & 33 & 25.3 & 3.3 & $2-7$ & 0.003 \\
\hline Above 120 DIM & 121 & 15 & 12.4 & Ref & & \\
\hline \multicolumn{7}{|l|}{$\mathrm{BCS}$} \\
\hline Thin & 58 & 16 & 27.5 & Ref & & \\
\hline Moderate & 166 & 26 & 15.6 & 0.9 & $0.2-3$ & 0.08 \\
\hline Fat & 27 & 6 & 22.2 & 0.3 & $0.1-1$ & 0.04 \\
\hline \multicolumn{7}{|l|}{$\mathrm{HCS}$} \\
\hline Normal & 170 & 24 & 14.1 & Ref & & \\
\hline Hair loss & 65 & 14 & 21.5 & 2.1 & $0.9-5$ & 0.08 \\
\hline Ulcer/Swelling & 16 & 10 & 62.5 & 4.8 & $5-17$ & 0.01 \\
\hline \multicolumn{7}{|l|}{ HS } \\
\hline Clean & 133 & 12 & 9.0 & Ref & & \\
\hline Dirty & 80 & 18 & 22.5 & 2.6 & $1.3-6.2$ & 0.04 \\
\hline Very dirty & 38 & 18 & 47.3 & 9.9 & $4-28$ & 0.001 \\
\hline \multicolumn{7}{|l|}{ Claw overgrowth } \\
\hline Absent & 179 & 25 & 13.9 & Ref & & \\
\hline Present & 72 & 23 & 31.9 & 2.0 & $0.9-5$ & 0.071 \\
\hline
\end{tabular}

Ref reference category

$* P$ values $<0.05$ are considered statistically significant 
Table 5 Relationship between cow level factors and occurrence of claw lesions in the dairy cows using binary logistic regression

\begin{tabular}{|c|c|c|c|c|c|c|}
\hline Factors & $\begin{array}{l}\text { Observations } \\
(n=251)\end{array}$ & $\begin{array}{l}\text { Cows with claw } \\
\text { lesions }\end{array}$ & $\%$ & OR & $\begin{array}{l}95 \% \\
\mathrm{CI}\end{array}$ & $\begin{array}{l}P \\
\text { value }\end{array}$ \\
\hline \multicolumn{7}{|l|}{ Parity } \\
\hline Primiparous & 59 & 12 & 20.3 & Ref & & \\
\hline 2nd parity & 103 & 27 & 26.2 & 1.7 & $0.7-4$ & 0.27 \\
\hline Parity 3 and above & 99 & 39 & 39.4 & 1.6 & $0.7-4$ & 0.31 \\
\hline \multicolumn{7}{|l|}{ DIM } \\
\hline $\begin{array}{l}1-120 \text { days in } \\
\text { milk }\end{array}$ & 130 & 33 & 25.4 & 0.6 & $0.3-1$ & 0.11 \\
\hline Above 120 DIM & 121 & 45 & 37.2 & Ref & & \\
\hline \multicolumn{7}{|l|}{$\mathrm{BCS}$} \\
\hline Thin & 58 & 24 & 41.4 & Ref & & \\
\hline Moderate & 166 & 44 & 26.5 & 0.4 & $0.1-1$ & 0.12 \\
\hline Fat & 27 & 10 & 37.0 & 0.2 & $0.1-1$ & 0.003 \\
\hline \multicolumn{7}{|l|}{$\mathrm{HCS}$} \\
\hline Normal & 170 & 48 & 28.2 & Ref & & \\
\hline Hair loss & 65 & 20 & 30.8 & 1.6 & $0.8-3$ & 0.23 \\
\hline Ulcer/Swelling & 16 & 10 & 62.5 & 1.9 & $0.6-6$ & 0.30 \\
\hline \multicolumn{7}{|l|}{ HS } \\
\hline Clean & 133 & 18 & 13.5 & Ref & & \\
\hline Dirty & 80 & 33 & 41.3 & 4.9 & $4-11$ & 0.001 \\
\hline Very dirty & 38 & 27 & 71.1 & 15.4 & $6-40$ & 0.001 \\
\hline \multicolumn{7}{|l|}{ Claw overgrowth } \\
\hline Absent & 179 & 41 & 22.9 & Ref & & \\
\hline Present & 72 & 37 & 51.4 & 2.7 & $1.4-5.3$ & 0.005 \\
\hline
\end{tabular}

there were significant associations between lameness prevalence and cows at early lactation, injured hocks, and dirty leg hygiene as reported by other similar studies (Bergsten et al. 2015; Relun et al. 2013; Nash et al. 2016). The structural changes in the claw capsule from hormonal effect at pericalving period and higher milk yield were suggested to influence the increased odds of clinical lameness at early days in milk (Newsome et al. 2017). Equally, hock injuries were reported in lame cows having spent more time lying down on hard and abrasive surfaces (Nash et al. 2016). Accordingly, 5 of the studied farms had bare concrete floors which could have increased the severity of hock lesions. Likewise, exposure of the cow foot to manure slurry and poor leg cleanliness was found to enhance claw conformational changes leading to lameness (Relun et al. 2013). The association between claw overgrowth and lameness occurrence as shown herein has been demonstrated in previous studies indicating the importance of claw trimming (Solano et al. 2015). Consequently, only 2 of the studied farms practiced claw trimming. Overall, the prevalence of claw lesions was associated with dirty leg hygiene and overgrown claw. Poor leg hygiene augments the development of either infectious or claw horn lesions by exposing the feet to manure and moisture with detrimental effect on claw health (Relun et al. 2013). Other factors such as early lactation, parity, BCS, and hock condition were not associated with prevalence of claw lesions in contrary to other studies (Ranjbar et al. 2016: Solano et al. 2016). The disparity might be credited to difference in breeds and distribution of claw lesions. Nevertheless, the result herein as related to BCS and parity is consistent with results of Ristevski et al. (2016) and Olechnowicz et al. (2011), respectively.

The recorded prevalence estimates indicates that lameness and claw lesions are important health issues in the studied farms. Farmers need to improve the management of cows in early lactation, injured hock condition, leg cleanliness, and overgrown claw. Lameness occurrence and claw lesions could be reduced in dairy herds in the region based on the generated knowledge and information to the farmers and veterinarians. Further studies are required to investigate herd-level risk factors associated with lameness and specific claw lesions in dairy herds in the region.

Acknowledgements This study was supported by the Universiti Putra Malaysia research grant number 9507600. The authors thank the Division of Veterinary Services (DVS), Selangor, Malaysia, for their assistance. Also, we appreciate the farmers for their cooperation to participate in the 
study and all the technical staff of the Department of Medicine and Surgery of Farm and Exotic Animals, Faculty of Veterinary Medicine UPM Serdang Selangor, Malaysia.

\section{Compliance with ethical standards}

Conflict of interest The authors declare that they have no conflicting interest.

Ethical statement This study was approved by the Human Ethics Committee of the University Putra Malaysia (Ref: FPSK-P083)2017 and Institution of Animal Care and Use Committee (UPM/IACUC/ AUP-R028/2017) for the use of animals in the study.

Open Access This article is distributed under the terms of the Creative Commons Attribution 4.0 International License (http:// creativecommons.org/licenses/by/4.0/), which permits unrestricted use, distribution, and reproduction in any medium, provided you give appropriate credit to the original author(s) and the source, provide a link to the Creative Commons license, and indicate if changes were made.

\section{References}

Archer, S.C., Newsome, R., Dibble, H., Sturrock, C.J., Chagunda, M.G., Mason, C.S., and Huxley, J.N., 2015. Claw length recommendations for dairy cow foot trimming, Veterinary Record, 177, 222

Asit, C., and Pankaj, K., 2016. Incidences of foot diseases of cattle in Bihar, Indian International Journal of Agricultural Sciences and Research, 6, 267-272

Becker, J., Steiner, A., Kohler, S., Koller-Bahler, A., Wuthrich, M., and Reist, M., 2014. Lameness and foot lesions in Swiss dairy cows: II. Risk factors, Schweiz Arch Tierheilk, 156, 79-89

Bergsten, C., Telezhenko, E., and Ventorp M., 2015. Influence of soft or hard floors before and after first calving on dairy Heifer locomotion, claw and leg health. Animals (Basel), 5, 662-686

Chapinal, N., Liang, Y., Weary, D.M., Wang, Y., and von Keyserlingk, M.A., 2014. Risk factors for lameness and hock injuries in Holstein herds in China, Journal of Diary Science, 97, 4309-4316

Cook N.B., Hess, J.P., Foy, M.R., Bennett, T.B., and Brotzman, R.L., 2016. Management characteristics, lameness, and body injuries of dairy cattle housed in high-performance dairy herds in Wisconsin, Journal of Dairy Science, 99, 5879-5891

DairyCo 2007. DairyCo Mobility Score. DairyCo, Kenilworth

DVS, 2014. Annual Reports: Department of Veterinary Services, Malaysia

Elanco Animal Health, 2009. Body condition scoring. Bulletin AI 8478, Rev. 9/09. Elanco Animal Health, Indianapolis.

FAO, 2015. Food outlook: Biannual report on global food markets. 2015. http://www.fao.org/3/a-i5003e.pdf/. Accessed 20 Jan 2017

Gibbons, J., Vassuer, E., Rushen, J., and de Passillé, A.M., 2012. A training programme to ensure high repeatability of injury scoring of dairy cows, Animal Welfare, 21, 379-388

Gomez, A., Cook, N.B., Rieman, J., Dunbar, K.A., Cooley, K.E., Socha, M.T., and Dopfer, D., 2015 The effect of digital dermatitis on hoof conformation. Journal of Dairy Science, 98, 927-936.

Green, L.E., Huxley, J.N., Banks, C., and Green, M.J., 2014. Temporal associations between low body condition, lameness and milk yield in a UK dairy herd. Preventive Veterinary Medicine, 113, 63-71.

Horseman, S.V., Roe, E.J., Huxley, J.N., Bell, N.J., Mason, C.S., and Whay, H.R., 2014 The use of in-depth interviews to understand the process of treating lame dairy cows from the farmer's perspective. Animal Welfare, 23, 2, 157-165.

International Claw Health Atlas (ICAR) 2015 First edition ICAR Via Savoia 78, Scala A, Int. 3, 00191, Rome, Italy

Nash, C.G., Kelton D.F., DeVries, T.J., Vasseur, E., Coe, J., Heyerhoff, J.C., Bouffard, V., Pellerin, D., Rushen, J., de Passille, A.M., and Haley, D.B., 2016 Prevalence of and risk factors for hock and knee injuries on dairy cows in tiestall housing in Canada. Journal of Dairy Science, 99, 6494-6506

Newsome, R.F., Green, M.J., Bell, N.J., Bollard, N.J., Mason, C.S., Whay, HR, and Huxley, J.N., 2017 A prospective cohort study of digital cushion and corium thickness. Part 2: Does thinning of the digital cushion and corium lead to lameness and claw horn disruption lesions? Journal of Dairy Science, 100, 4759-4771.

Olechnowicz, J., and Jaskowski, J.M., 2011. Behaviour of lame cows: A review. Veterinary Medicine, (Praha), 56, 581-588

Olechnowicz, J., Jedrzej, M., and Jaskowski, J.M., 2011. Impact of clinical lameness, calving season, parity, and month of lactation on milk, fat, protein, and lactose yields during early lactation of dairy cows. Bulletin of the Veterinary Institute in Pulawy, 54, 605-610

Palmer, M.A., and O'Connell, N.E., 2015 Digital dermatitis in dairy cows: a review of risk factors and potential sources of betweenanimal variation in susceptibility. Animals (Basel), 5, 512-535.

Rahman, M.A, Imtiaz, M.A., Ahaduzzaman, M., Ghosh, K.K., Masud, A.A., Chowdhury, S., and Sikder, S., 2014. Effects of flooring and rearing system on hoof health of dairy cows in some selected areas of Bangladesh, Bangladesh Journal of Animal Science, 43, 132-137

Ranjbar, S., Rabiee, A.R., Gunn, A., and House, J.K., 2016. Identifying risk factors associated with lameness in pasture-based dairy herds, Journal of Dairy Science, 99, 7495-7505

Relun, A., Lehebel, A., Chesnin, A., Guatteo, R., and Bareille, N., 2013 Association between digital dermatitis lesions and test-day milk yield of Holstein cows from 41 French dairy farms. Journal of Dairy Science, 96, 2190-2200

Ristevski, M., Toholj, B., Cincović, M., Boboš, S., Trojačanec, P., Stevančević, M., and Ozren, S., 2016 Influence of body condition score and ultrasound-determined thickness of body fat deposit in holstein-Friesian cows on the risk of lameness developing. Journal of the Faculty of Veterinary Medicine, University of Kafkas, 10, 30 37

Shearer, J.K., 2017 Bovine Lameness. Veterinary Clinics of North American Food Animal Practice, Volume 33, Issue 2, 33, xiii-xi

Shearer J.K., and van Amstel S.R., 2013 Manual of Foot Care in Cattle. Hoard's Dairyman, Fort Atkinson

Solano, L., Barkema, H.W., Pajor, E.A., Mason, S., LeBlanc, S.J., Zaffino Heyerhoff, J.C., Nash, C.G., Haley, D.B., Vasseur, E., Pellerin, D., Rushen, J., de Passille, A.M., and Orsel, K., 2015. Prevalence of lameness and associated risk factors in Canadian Holstein-Friesian cows housed in freestall barns, Journal of Dairy Science, 98, 69786991

Solano, L., Barkema, H.W., Mason, S., Pajor, E.A., LeBlanc, S.J., and Orsel, K., 2016. Prevalence and distribution of foot lesions in dairy cattle in Alberta, Canada, Journal of Dairy Science, 99, $6828-6841$

Somers, J., and O'Grady, L., 2015. Foot lesions in lame cows on 10 dairy farms in Ireland, Irish Veterinary Journal, 68, 10

Tadich, N., Flor, E., and Green, L., 2010. Associations between hoof lesions and locomotion score in 1098 unsound dairy cows, Veterinary Journal, 184, 60-65

Thoefner, M.B., Pollitt, C.C., van Eps, A.W., Milinovich, G.J., Trott, D.J., Wattle, O., and Anderson, P.H., 2004 Acute bovine laminitis: A new induction model using alimentary oligofructose overload. Journal of Dairy Science, 87, 2932-2940 
Thomas, H.J, Remnant, J.G, Bollard, N.J, Burrows, A., Whay, H.R., Bell, N.J, Mason, C., and Huxley, J.N., 2016. Recovery of chronically lame dairy cows following treatment for claw horn lesions: a randomised controlled trial. Veterinary Record, 178, 116.

Thrusfield, M.V. 2005. Veterinary Epidemiology, 3rd Ed. Blackwell Sc Ltd. UK

Van Nuffel, A, Zwertvaegher, I., Van Weyenberg, S., Pastell, M., Thorup, V.M., Bahr, C., Sonck, B., and Saeys, W., 2015. Lameness detection in dairy cows: part1. How to distinguish between non-lame and lame cows based on differences in locomotion or behavior. Animals 5 , $838-860$

Whay, H.R., and Shearer, J.K., 2017. The impact of lameness on welfare of the dairy cow. Veterinary Clinics of North American Food Animal Practice, 33, 153-164.

Zahid, U.N., Randhawa, S.S., Hussain, S.A., Randhawa, S.S., Mahajan, V., and Dua, K., 2014. Claw lesions causing clinical lameness in lactating Holstein Fresian crossbred cows. Veterinary Medicine International, Article ID 764689 